\title{
A Useful Exploration to Improve the Quality of Rural School Education
}

\author{
Xiaoqiao Cheng \\ School of Institute of Education Science, Nanjing Normal University, Nanjing 210097, \\ Jiangsu, China
}

"My vision for the country is to urbanise rural areas. What is available in the cities must be available in the villages."

-Jaggi Vasudev

$\mathrm{T}$ HE British educational sociologist B. Bernstein (2003) believed that in human social communication, the language signs used by people can be divided into exquisite signs and restrictive signs. Exquisite symbols include the arrangement of complex grammatical sentences and general semantics; while restricted symbols consist of simple, low-selective and restricted grammars and words, relying on the semantics of a specific context. Children born in middle-class families are familiar with and mastered exquisite symbols in their interactions with their parents, which is the basis for them to easily obtain excellent academic studies. Children born in poor families are familiar with restrictive symbols in their interactions with their parents. The language symbols used in the school education environment are mostly exquisite symbols, or standard academic language. If children from poor families cannot master the exquisite symbols, it will affect their understanding of the learning content, prone to learning difficulties, and lead to poor academic achievement.

In the process of school science education, due to its subject characteristics, teachers need to use scientific academic language to teach, and students need to use scientific academic language to understand the content of scientific knowledge, otherwise it will affect students' scientific academic achievements. To this end, teachers need to understand students' language

(c) 2021 Insights Publisher. All rights reserved.

(i) (-) Creative Commons Non Commercial CC BY-NC: This article is distributed under the terms of the Creative Commons Attribution-NonCommercial 4.0 License (http://www.creativecommons.org/licenses/by-nc/4.0/) which permits non-commercial use, reproduction and distribution of the work without further permission provided the original work is attributed by the Insights Publisher. 
usage habits, consciously create a learning environment, and train students to understand the core concepts of science through learning and mastering scientific academic language, so as to describe the observed scientific phenomena. These are relatively easy for teachers in urban schools to do because their family background or living environment provides them with convenient conditions. But for teachers in rural schools, due to their family background or living environment, and long-term dealings with children from poor rural families and their parents, they are accustomed to using restricted symbols (popular language) to communicate with children. Obviously, this kind of teaching language habit of teachers is not conducive to the teaching of science courses, and the result is bound to affect the scientific academic achievements of rural school students. Therefore, if we want to improve the scientific academic achievement of rural school students, we must start with training rural school teachers and at the same time reform the curriculum of rural school science education.

The article entitled Investigating the Impact of Literacy-infused Science Intervention on Economically Challenged Students' Science Achievement: A Case Study from a Rural District in Texas published in this issue of the journal is about the impact of educational interventions on the scientific and academic achievements of students from economically challenged rural families (Irby et al., 2021). The purpose of this study was to explore a new way to improve the teaching ability of rural school science teachers and the scientific academic achievement of rural school students. The research interventions included: training and guidance for teachers, implementing science courses that include scientific and language goals, and developing students' scientific academic vocabulary and concepts through listening, speaking, reading, and writing. This experimental study proved that providing students with opportunities to practice language skills and organically combining language teaching with science subject teaching will help rural students achieve higher academic achievements. This study also showed that the abstract and normative characteristics of science subjects make it difficult for students in rural schools to learn and understand the content of science subjects. To reduce the difficulties for students in learning science courses, it is necessary to improve the teaching ability of teachers in rural schools, especially the teaching ability of science teachers. Therefore, to implement such a teaching strategy in rural schools, it is necessary to strengthen the training and guidance of teachers, as well as provide support for various resources.

This study has proved B. Bernstein's theory of language signs in practice, that is, to improve the academic achievement of rural school students, it is necessary to help students from economically challenged rural families' master exquisite signs. To achieve this goal, teachers in rural schools must be trained to organically embed the task of language teaching in subject teaching. Undoubtedly, this study has enriched the research content of rural education and provided a new idea for improving the quality of rural education. 


\section{References}

Bernstein, B. (2003). Class, codes and control. Vol I. London: Routledge. pp62-pp63. Last access: June 27, 2021. Retrieved from:

https://anekawarnapendidikan.files.wordpress.com/2014/04/class-codes-andcontrol-vol-1 -theoretical-studies-towards-a-sociology-of-language-by-basibernstein.pdf

Irby, B.J., Tong, F., Lara-Alecio, R., Tang, S., Guerrero, C., Wang, Z., \& Zhen, F. (2021). Investigating the impact of literacy-infused science intervention on economically challenged students' science achievement: A case study from a rural district in Texas. Science Insights Education Frontiers, 9(1):1123-1141. DOI:

https://doi.org/10.15354/sief.21.or033

Correspondence to:

Xiaoqiao Cheng, Ph.D.

Nanjing Normal University

Nanjing 210097, Jiangsu

China.

Email:xqcheng2008@vip.163.com

Conflict of Interests: None.

Doi: 10.15354/sief.21.co011 